\title{
The Diploma in Mountain Medicine
}

\author{
MJ Brookes, P Richards
}

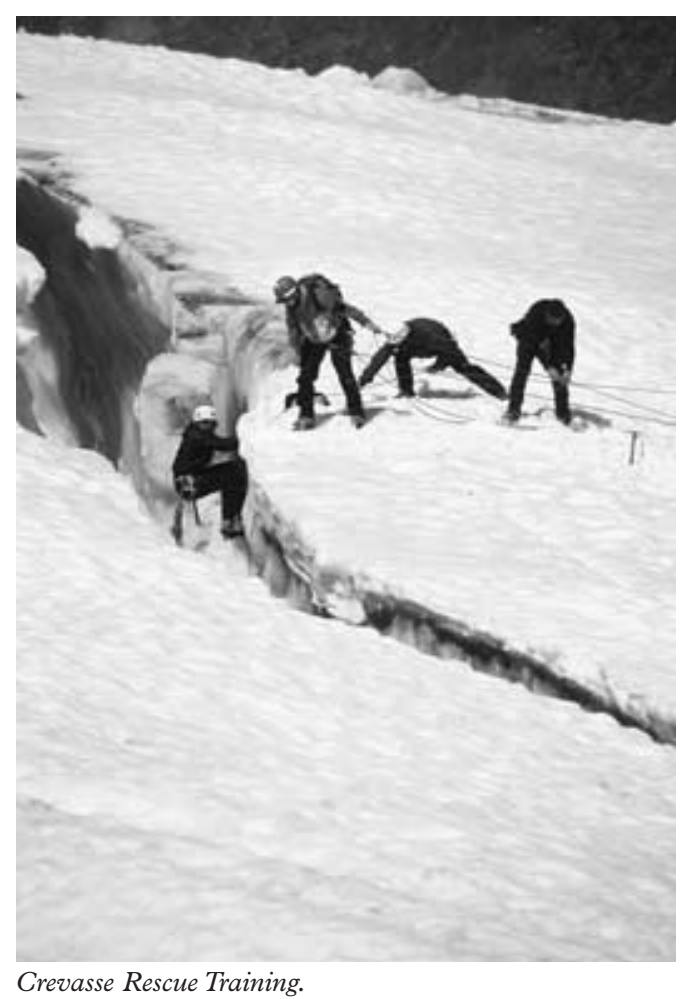

\section{Introduction}

With the clinical phenomenon of 'diplomatosis' being recently documented (1) questions may be asked as to the necessity of a diploma in mountain medicine. Mainland Europeans, however, have long since taken the provision of prehospital care in a mountain environment a lot more seriously. Alpine countries have fulltime, salaried mountain rescue services, which are usually a division of the police or armed forces. Doctors serving with these rescue services must hold the diploma in mountain medicine as proof that their clinical and practical skills meet a required standard in order to operate as an effective member of a mountain rescue team (2). The diploma is run in conjunction with UIAA (Union Internationale Des Associations D'Alpisme - the International Mountaineering and Climbing Federation) and IKAR (International Committee for Alpine Rescue).

The situation in the United Kingdom is very different. The Mountain Rescue Council oversees 69 different rescue teams, which operate semi-autonomously. Each team usually has one or more doctors volunteering their services, and there is a wide range of experience within the cohort of mountain rescue doctors. There is no mandatory qualification for service as a team doctor

Increasingly clinicians are also consulted by patients who are preparing to depart or who have recently returned from expeditions at high altitude, often in remote areas. Patients often require specialised advice, such as management of frostbite injury (3). At present, there is an ad hoc arrangement where doctors may ask the British Mountaineering Council (BMC) for advice, and the BMC will pass the questions onto their medical panel. A national web-based forum is currently being established for doctors who have an interest in, or questions about, high altitude medicine (4).

A working knowledge of the effects of high altitude is becoming more important with ongoing military operations in mountainous regions, such as Afghanistan $(5,6)$. Military Medical Officers must be able to recognise the symptoms and signs of altitude related disease early and treat casualties urgently, especially as mountainous regions are associated with long evacuation times and casualties can deteriorate quickly if left at altitude or treated inappropriately. Recent service expeditions have experienced these phenomena (7).

\section{The Diploma}

The Diploma in Mountain Medicine is administered by Medical Expeditions, a charity with the remit to promote research and education on high altitude physiology and medicine. It is approved as a diploma by UIAA, IKAR and the International Society of Mountain Medicine. (ISMM). It is also currently approved as a Certificate in Mountain Medicine by the University of Leicester, (although status as a university Diploma is pending), with future plans to extend the option of progression to an $\operatorname{MSc}(8)$

The diploma consists of four modules (see Appendix 1):

- Altitude and environmental medicine and physiology.

- Travel and expedition medicine.

- Mountain rescue and traumatology.

- Personal mountaineering skills.

The modules are taught over four periods of student contact. Two periods are held at Plas-Y-Brenin, Snowdonia, one period is 
held at Fort William and the final period is held at Arolla in the Swiss Alps. Each session requires pre and post course assessments, which are usually MCQs, and six short answer questions of a similar format to the Diploma in Immediate Care of The Royal College of Surgeons of Edinburgh. There is also continuous assessment from the tutors and mountaineering instructors during the contact periods.

It is possible to complete the diploma in a year and all candidates are encouraged to finish within two. On application, diplomats have up to four years to pass all four modules, which is useful for military candidates.

\section{Pre-entry Requirements}

Candidates must hold full GMC registration and possess personal mountaineering skills described as 'a high level of performance at a relatively low standard'. Individual skills vary, but the UIAGM guides provide instruction to all candidates in order to ensure best practice. Candidates should be able to navigate with confidence, be able to look after themselves in the field and have a basic knowledge of ropework. Those lacking basic skills may be asked to resit elements of the modules. A list of useful reading is given at Appendix 2.

\section{Costs}

The cost of the Diploma is $£ 2000$. However, this does not include transport costs or accommodation costs in Scotland or the Alps, which are several hundred pounds. Candidates use their own mountaineering equipment on the course. Most diplomats do not incur any extra cost hiring or purchasing equipment as most already own basic kit such as an ice-axe and crampons.

\section{Personal Experience as a \\ Candidate}

The modules are very intense, and feature some esteemed international speakers such Professor John West and Dr Jim Milledge, who are pioneers and leaders in the field of high altitude medicine. Other lecturers from the Scottish Mountain rescue teams are able to impart immense practical advice from their many years of experience at the 'sharp end'. The mountain instructors are all qualified UIAA guides and provide superb instruction and useful tips to the more experienced mountaineer. They also have good first hand knowledge of field first aid and rescue in situations such as avalanche, and their case reports make interesting learning.

Military medical officers may find some aspects of the course well within their grasp, as most have had exposure to pre-hospital work and had experience with rotary wing evacuation. There are no considerations of previous experience, but the modules are worth attending in their entirety as there is always something to learn from an extremely experienced and diverse faculty.

Doctors who are less confident with their mountaineering skills would benefit from attending a Mountain Leader Training course (MLT) or a Winter Mountain Leader Training course, both available from the Joint Service Mountain Training Centre via the unit training wing.

\section{Conclusion}

The Diploma is evolving rapidly in this its first year in the UK. At times, it may seem disjointed, but this will always be the case with a brand new course and with 20 doctors all in the same place at the same time. The diploma is ideal for military doctors advising or accompanying service groups travelling to high altitude areas both for adventurous training and for operations, and for those who wish to widen their pre-hospital care interest to encompass mountain rescue.

\section{References}

1. Easton G. Writing for the new diplomatosis column. BMJ Careers 2004; 7 Aug: 57.

2. Scrimgeour C. Mountain rescue medicine in France. BMJ Careers 2004; 19 Jul: 17-18.

3. Minerva. Brit Med J 2004; 328: 1210.

4. Personal communication Brookes/Hillebrandt.

5. Grau L, Jorgensen W. Medical implications of high altitude combat. Fournal of Special Operations Medicine 2003; Dec: 30-38.

6. Sawhney P. Kashmir's cold war. Fanes International Defense Review 1997; Dec: 58-61.

7. Blackwood I. Rescue from White Rocks Aconcagua Army Mountaineer 2004; Summer: 20-22.

8. Barry P. Mountain Medicine Training. http:/ careerfocus.bmjjournals.com/cgi/eletters/327/7407/ s17-a\#34843, 24 Jul 2003 accessed on 23 Aug 04.

\section{Conflict of Interest}

MJB is a member of the Diploma Faculty. He has led and participated in several highaltitude expeditions, is a member of Medex and a Team Doctor for Swaledale Mountain Rescue Team.

PR is a Diploma Faculty member and a director of Medical Expeditions. He has participated in numerous high altitude research and climbing expeditions and has acted as a consultant to Jagged Globe and World Challenge expedition companies. 
Appendix 1.

Summary of Syllabus

\begin{tabular}{|c|c|}
\hline \multicolumn{2}{|c|}{\begin{tabular}{|l|} 
Module 1 \\
Altitude and Environmental Medicine and Physiology \\
\end{tabular}} \\
\hline Altitude & $\begin{array}{l}\text { Physiology, features and diagnosis of Acute Mountain } \\
\text { Sickness, High Altitude Cerebral Oedema and High } \\
\text { Altitude Pulmonary Oedema }\end{array}$ \\
\hline Hypothermia & $\begin{array}{l}\text { Prevention, protection and evacuation of casualties. Field } \\
\text { and hospital treatment }\end{array}$ \\
\hline Cold & Prevention and treatment of cold injuries \\
\hline Heat And Solar Radiation & High altitude skin and eye problems \\
\hline Children In The Mountains & Special considerations with children at altitude \\
\hline Nutrition & Expedition diet, hydration and hygiene \\
\hline Physiology & $\begin{array}{l}\text { Sports and exercise physiology pertaining to mountain } \\
\text { performance }\end{array}$ \\
\hline \multicolumn{2}{|l|}{ Stress Management } \\
\hline $\begin{array}{l}\text { Pre-Existing Medical } \\
\text { Conditions }\end{array}$ & $\begin{array}{l}\text { Giving advice and managing complications of pre- } \\
\text { existing medical conditions }\end{array}$ \\
\hline $\begin{array}{l}\text { Medical Problems In } \\
\text { Remote Areas }\end{array}$ & Diabetes, Asthma, Acute Coronary Syndromes \\
\hline Avalanche And Weather & $\begin{array}{l}\text { The effects of weather on mountain safety. Avalanche } \\
\text { prediction and safety }\end{array}$ \\
\hline
\end{tabular}

\begin{tabular}{|l|l|}
\hline $\begin{array}{l}\text { Module 2 } \\
\text { Travel and Expedition Medicine }\end{array}$ \\
\hline Member Selection & Personality and existing illness \\
\hline $\begin{array}{l}\text { Risk Assessment, Legal } \\
\text { Aspects And Insurance }\end{array}$ & \\
\hline Medical Kits & \\
\hline Immunisations & \\
\hline Malaria & \\
\hline $\begin{array}{l}\text { Other Animals That } \\
\text { Cause Problems }\end{array}$ & Leeches, scorpions, snakes etc \\
\hline Water And Food & Water purification systems \\
\hline Gastroenteritis & Types and treatments \\
\hline Hygiene & \\
\hline Sexual Health & Health and contraception on expeditions \\
\hline Dental & Preparation and field treatment \\
\hline Rescue & $\begin{array}{l}\text { International aspects. Evacuation planning. First Aid } \\
\text { training for team members }\end{array}$ \\
\hline
\end{tabular}

Module 3

Mountain Rescue and Traumatology

\begin{tabular}{|ll|}
\hline Organisation & Teams in UK and abroad \\
\hline Communications & \\
\hline
\end{tabular}




\begin{tabular}{|l|l|l|l|}
\hline $\begin{array}{l}\text { Appendix 2. } \\
\text { Further Reading }\end{array}$ & Author & Publisher and Date & Comments \\
\hline Name & $\begin{array}{l}\text { Andrew Pollard, } \\
\text { David Murdoch }\end{array}$ & $\begin{array}{l}\text { Radcliffe Medical } \\
\text { Press 2003 }\end{array}$ & $\begin{array}{l}\text { Updated, very } \\
\text { useful basic } \\
\text { reference text }\end{array}$ \\
\hline $\begin{array}{l}\text { The High Altitude } \\
\text { Medicine Handbook }\end{array}$ & $\begin{array}{l}\text { Michael Ward, } \\
\text { James Milledge } \\
\text { and John West }\end{array}$ & Arnold 2000 & $\begin{array}{l}\text { Expent definitive } \\
\text { text }\end{array}$ \\
\hline $\begin{array}{l}\text { High Altitude Medicine } \\
\text { and Physiology }\end{array}$ & & www.medex.org.uk & \\
\hline Medex & Sarah Anderson & Profile Books 2002 & $\begin{array}{l}\text { Adventurous } \\
\text { training courses }\end{array}$ \\
\hline JSP 419 & & $\begin{array}{l}\text { Good, basic } \\
\text { advice for a } \\
\text { variety of } \\
\text { expedition } \\
\text { environments }\end{array}$ \\
\hline $\begin{array}{l}\text { Expedition } \\
\text { Medicine }\end{array}$ & Pete Hill, \\
Stuart Johnston & David and Charles 2000 & $\begin{array}{l}\text { Current } \\
\text { definitive text } \\
\text { for } \\
\text { mountaineering } \\
\text { skills }\end{array}$ \\
\hline $\begin{array}{l}\text { The Mountain Skills } \\
\text { Training Handbook }\end{array}$ & & Pelham Books 1997 & $\begin{array}{l}\text { Thorough text } \\
\text { in climbing and } \\
\text { mountaineering }\end{array}$ \\
\hline $\begin{array}{l}\text { The Handbook of } \\
\text { Climbing }\end{array}$ & $\begin{array}{l}\text { Allen Fyffe, } \\
\text { Iain Peter }\end{array}$ & www.ikar-cisa.org & \\
\hline IKAR & & www.ismmed.org & \\
\hline ISMM & & & \\
\hline UIAA & & & \\
\hline
\end{tabular}

\begin{tabular}{|l|l|}
\hline $\begin{array}{l}\text { Module 3. } \\
\text { Mountain Rescue and Traumatology }\end{array}$ & \\
\hline Organisation & Teams in UK and abroad \\
\hline Communications & \\
\hline Patient Assessment & \\
\hline Improvised Rescue Techniques & Accepted search and rescue techniques \\
\hline Rescue Techniques & \\
\hline Patient Packaging & $\begin{array}{l}\text { Type, costs, working environment and } \\
\text { limitations }\end{array}$ \\
\hline Patient Transport & $\begin{array}{l}\text { Drugs, IV fluids, chest drain, } \\
\text { immobilisation }\end{array}$ \\
\hline Helicoptors & $\begin{array}{l}\text { Types, routes of administration and } \\
\text { internal regulations in controlled drug use }\end{array}$ \\
\hline Field Treatments & \\
\hline Analgesia &
\end{tabular}

\begin{tabular}{|l|l|}
\hline $\begin{array}{l}\text { Module 4. } \\
\text { Personal Mountaineering Skills }\end{array}$ & \\
\hline Navigation & $\begin{array}{l}\text { Effective navigation in poor visibility } \\
\text { including darkness }\end{array}$ \\
\hline Shelter & $\begin{array}{l}\text { Use of group shelters, tents and snow-holes } \\
\text { Patient Assessment }\end{array}$ \\
\hline Personal Care & $\begin{array}{l}\text { Basic tenets of personal administration in } \\
\text { the field }\end{array}$ \\
\hline Technical & Construct belays on snow, rock and ice \\
\hline Avalanche And Weather & $\begin{array}{l}\text { Basic knowledge of weather systems and } \\
\text { avalanche safety. Conduct searches } \\
\text { with/without avalanche transceivers }\end{array}$ \\
\hline Rescue & $\begin{array}{l}\text { Abseil, prussic, arrange simple hoist and } \\
\text { crevasse rescue }\end{array}$ \\
\hline
\end{tabular}

